\title{
PSA Level Less than or Equal to Eighty
}

National Cancer Institute

\section{Source}

National Cancer Institute. PSA Level Less than or Equal to Eighty. NCI Thesaurus. Code C137700.

A blood concentration of prostate specific antigen less than or equal to $80 \mathrm{ng} / \mathrm{mL}$. 